\title{
UMA DISCUSSÃO SOBRE OS SENTIDOS DA INTEGRAC̣ÃO DE FERIADOS, FESTAS E COMEMORACÕES CÍVICAS NO CALENDÁRIO DAS ESCOLAS PRIMÁRIAS PAULISTAS (1890-1930)
}

\author{
Rita de Cassia Gallego \\ Universidade de São Paulo (USP) \\ Renata Marcílio Cândido** \\ Universidade Federal de São Paulo (UNIFESP)
}

RESUMO: O presente artigo articula dois elementos que se complementam em estudos da história da cultura escolar. o tempo e as festas escolares. Os anos entre 1890 e 1930 são marcados pelos esforços estatais de implementar um sistema de ensino público em São Paulo, percebidos na profusão de reformas, na elaboração de leis, na construção de prédios escolares, em iniciativas de formação e organização de professores, na divulgação de saberes pedagógicos, entre outros. Nesse contexto, o detalhamento do calendário e, especialmente, a determinação dos dias de comemorações escolares integram as ações para se constituir um sistema de ensino com funcionamento homogêneo das escolas. $\mathrm{O}$ corpus documental a partir do qual se realizou o estudo constituiu-se de textos de revistas pedagógicas, relatórios de inspetores escolares, da legislação educacional e de outras obras literárias publicadas no período e que abordaram os temas em questão.

Palavras-chave: História da educação. Tempo escolar. Festa escolar.

http://dx.doi.org/10.1590/0102-4698116799

* Doutora em Educação pela Universidade de São Paulo (USP). Professora da Faculdade de Educação e do Programa de Pós-Graduação em Educação da Universidade de São Paulo (USP). E-mail: ritagallego@usp.br

* * Doutora em Educação pela Universidade de São Paulo (USP). Professora do Departamento da Educação da Universidade Federal de São Paulo (UNIFESP). E-mail: remarcilio@gmail.com 


\title{
A DISCUSSION ABOUT THE SENSES OF THE INTEGRATION OF HOLIDAYS, FESTIVALS AND CIVIC CELEBRATIONS IN PRIMARY SCHOOLS' CALENDAR IN SÃO PAULO (1890-1930)
}

\begin{abstract}
This article articulates two elements that are complementary in studies of the history of the school culture: the time and school parties. The years between 1890 and 1930 were marked by state efforts to implement a public education system in Sao Paulo, spotted in the profusion of reforms, formulation of laws, construction of school buildings, training initiatives and organization of teachers, dissemination of educational knowledge, among others. In this context, the details of the calendar and especially the determination of the school celebration days integrate actions in order to constitute an education system with uniform functioning of schools. The corpus documentation, from which this study was achieved, consisted of educational texts, reports of school inspectors, educational legislation and other literary works published in the period that addressed the issues in question.
\end{abstract}

Keywords: History of education. School time. School party.

\section{INTRODUÇÃO}

O presente texto discute os sentidos da inserção de festas e comemorações cívicas no calendário das escolas primárias públicas paulistas entre os anos de 1890 e 1930¹. Esse momento histórico é importante porque o calendário propriamente escolar ganha contorno, sendo expressivos nesse sentido os anos finais do século XIX e os iniciais do século XX, momento em que, devido ao seu processo de institucionalização ${ }^{2}$, as escolas ${ }^{3}$ passam a ter, gradativamente, tempos distintos dos outros tempos sociais. As discussões aqui apresentadas são fruto dos esforços de articulação das pesquisas de mestrado e doutorado realizadas pelas autoras acerca da organização do tempo escolar e, no âmbito deste, das festas, objetos esses que se relacionam em perspectivas mais abrangentes com as histórias da profissão docente e da cultura escolar.

Para a análise da temática, foram tomados como fontes nucleares textos extraídos de periódicos educacionais produzidos no período, fontes que, segundo pesquisadores da área, constituem um "excelente observatório" (CATANI, 2003; CARVALHO, 1989) da constituição do campo educacional naquele contexto histórico. Entre os títulos selecionados constam: A Escola Pública (1895-1897), Revista de Ensino (1902-1919), Revista Escolar (1925-1927) e Educação (1927-1929). Além dos periódicos, integraram o corpus documental: legislação educacional, relatórios dos inspetores escolares e dois títulos publicados no período e que abordaram o tema das festas: As comemoraçôes cívicas e 
As Festas Escolares, Carlos A. Gomes Cardim (1916), e Alma Brasileira, de Assis Cintra (1916?), publicados em São Paulo.

Ao elegermos como objetos de estudo o tempo e as festas escolares, as considerações aqui tecidas integram as tentativas de compreender aspectos que compõem a cultura escolar, compreendida na perspectiva de Dominique Julia (2001) como

um conjunto de normas que definem conhecimentos a ensinar e condutas a inculcar, e um conjunto de práticas que permitem a transmissão desses conhecimentos e incorporação desses comportamentos; normas e práticas coordenadas a finalidades que podem variar segundo as épocas (finalidades religiosas, sociopolíticas ou simplesmente de socialização). (JULIA, 2001, p. 10)

As contribuições de Agostín Escolano (1999) também são incorporadas nas análises efetivadas, com base no qual se entende que a cultura escolar é composta por três culturas distintas: a empírica, produzida pelos docentes no exercício da profissão no dia a dia; científica ou pedagógica, elaborada pelas ciências da educação ou por acadêmicos; e a política ou normativa, que se refere à organização das escolas, ao conjunto de regras que ordenam seu funcionamento, conforme destaca Vidal (2005). Essa percepção é particularmente importante ao se examinarem a questão das festas, os modos de festejar e os seus sentidos, pois, embora as festas aconteçam no interior das escolas, sua integração no calendário é definida primeiro no âmbito legal (decretos e leis educacionais) e nas instruções dirigidas aos professores de como essas devem ser realizadas, as quais eram publicadas em revistas pedagógicas, relatórios e outros materiais produzidos no período. Os professores, por sua vez, nem sempre atendiam na íntegra às expectativas postas por essas orientações, a exemplo dos relatos dos inspetores que trazem indícios de como os professores davam conta das propostas de realização das festas, por exemplo. Assim, é fundamental se considerar o papel dos professores, especialmente na configuração da cultura escolar, pois esses realizavam a articulação incessante entre as solicitações legais e pedagógicas e as suas condições reais de trabalho.

Por outro lado, não se pode esquecer que a representação de algo, apesar de todo o esforço de universalização, pode ser apropriada de forma distinta pelos diferentes atores escolares (CHARTIER, 1990). De acordo com Chartier (1990):

\footnotetext{
A apropriação, tal como a entendemos, tem por objetivo uma história social das interpretações, remetidas para as suas determinações fundamentais (que são sociais, institucionais, culturais) e inscritas nas práticas específicas que as produzem. (CHARTIER, 1990, p. 26)
} 
Nesse sentido, a forma como os professores concebiam tais solenidades era diferente da forma como os idealizadores as pensavam, que, por sua vez, era diferente da forma como os alunos a vivenciavam, por exemplo. Para os professores, as festas poderiam ser mais uma atribuição, entre tantas, engendradas com o advento dos grupos escolares e a constituição de um sistema estatal de ensino. Para os alunos - neste caso, os depoimentos foram mais escassos e pouco divulgados nos periódicos de ensino -, a festa poderia ser um dia em que se comemorava a ruptura do calendário escolar, marcado por lições, sabatinas, cobranças, exames, provas, e um dia em que poderiam expressar-se mais livremente e de forma diversa daquela exigida diariamente no cotidiano escolar. Era um momento no qual o aluno cantava, recitava, jogava ao ar livre, confraternizava com outros colegas de outras escolas em piqueniques, passeios, passeatas, podia se expressar de forma desprendida linguisticamente, fisicamente e também emocionalmente. Já para os diretores escolares, era um momento para demonstrar o bom andamento da instituição de ensino sob sua responsabilidade e, para os inspetores escolares, o momento de comprovar o progresso do ensino nas escolas.

Chervel (1990), ao estudar a história das disciplinas escolares, também traz elementos importantes para se pensar outra dimensão da cultura escolar: os saberes produzidos na escola entendidos no espectro de um retorno social, como destaca Vidal (2005). As escolas, ao serem postas a festejar as datas cívicas, de encerramento do ano ou de inauguração, acabaram por instaurar símbolos (bandeira, hino etc.), referências e práticas sociais (como a importância da escolarização). Desconsiderar esse movimento de construção da cultura escolar é empobrecer as suas potencialidades analíticas e as influências que as histórias da festa e do tempo escolar possuem na constituição de uma história da cultura escolar em São Paulo.

Os trabalhos que tomam a cultura escolar como categoria de interpretação partem de diversas áreas disciplinares que compõem a pedagogia, como a psicologia da educação, a sociologia da educação, a filosofia da educação e a didática, traduzindo em modos próprios formas de lidar com o arsenal teórico, de assegurar procedimentos de validação das pesquisas e de legitimação das análises. Essas pesquisas têm permitido "desnaturalizar" a escola e empreender estudos sobre o processo de sua emergência como instituição de socialização nos tempos modernos. Tal perspectiva, conforme assinalado por Faria Filho et al (2004) a propósito das contribuições de Chervel (1990), traz como imperativo pensar a relação da escola com outras 
instituições responsáveis pela socialização da infância e da juventude, principalmente a família, a Igreja e o mundo do trabalho.

A constituição de um calendário específico no âmbito da cultura escolar deu-se no fim do século XIX e no início do século XX, momento no qual havia todo um esforço voltado para se concretizar a implementação de um sistema de ensino público paulista, a partir da realização de reformas, da elaboração de leis, da construção de prédios escolares, de iniciativas de formação e da organização de professores, além da divulgação de saberes pedagógicos, entre outras. Nesse contexto, o gradativo detalhamento do calendário e, especialmente, a determinação dos dias de festas e comemorações escolares integraram as ações para se constituir um sistema de ensino com funcionamento homogêneo das escolas, consoante com os ideais de difusão do ensino, além de serem tentativas para controlar as atividades escolares no momento da organização do sistema escolar estatal.

Durkheim (1989, p. 39) sublinha que "o calendário exprime o ritmo da atividade coletiva ao mesmo tempo que tem por função assegurar a sua regularidade". Suas divisões em dias, semanas, meses e anos "correspondem à periodicidade dos ritos, das festas, das cerimônias públicas" (DURKHEIM, 1989, p. 39). São eles signos temporais importantes, uma vez que expressam experiências e representações comuns a distintas sociedades, culturas, agrupamentos humanos, criando sentimentos e laços de pertencimento. Desse modo, os calendários tanto exprimem quanto direcionam os ritmos das práticas sociais, cadências da vida em comum. Le Goff (1984) destaca que toda vida (cotidiana, afetiva, fantástica) de uma sociedade depende de seu calendário e,

embora dependam do tempo cósmico, regulador da duração que se impõe a
todas as sociedades humanas [...] estas captam-no, medem-no e transformam-
no em calendário, segundo as suas estruturas sociais e políticas, os seus sistemas
econômicos e culturais, os seus instrumentos científicos e tecnológicos.
(LE GOFF, 1984, p. 265-268)

No caso do tempo moderno, percebem-se os calendários de maior penetração, que regulam a vida de toda uma sociedade, de um povo ou nação, bem como os mais restritos, a eles unidos, como os calendários escolares.

Em virtude da crescente participação do Estado na educação, os processos educativos, a estrutura organizativa das escolas, a exemplo do calendário, passam a ser mais racionalizados. Datas para o início e o fim das aulas, férias e comemorações são fixadas. Com outro modo de estruturar o tempo, as atividades dos professores e dos alunos são 
cada vez mais reguladas, e estes são submetidos a uma nova relação com o tempo. Os calendários, conforme destaca Teixeira (1999, p. 96), são um dos principais referentes temporais da escola e da experiência do tempo dos professores, já que estruturam e revelam a rítmica das práticas e das atividades de professores e alunos nos tempos cotidianos.

Ao serem analisados os dados dos calendários escolares, podem ser especificados vários períodos e temporalidades, os quais delimitam conjuntos de tempos/atividades, como os dias de trabalho e os de descanso (início e término das aulas, feriados, recessos, férias), as subunidades de temporalização - como semestres, trimestres, bimestres, quinzenas, semanas e dias letivos -, os períodos festivos e comemorativos, as datas pedagógicas especiais (datas dos exames, por exemplo), os períodos não letivos (matrícula, por exemplo), as datas de reuniões de professores etc. Tem-se o ano civil, o ano religioso, com seus começos (primeiro de janeiro) e seus fins (31 de dezembro), como se tem o primeiro e o último dia do ano letivo escolar. Conjugados ao calendário civil e ao religioso do país, esses signos temporais normatizam o cotidiano da escola e de seus sujeitos, assim como todo o transcurso de uma trajetória escolar (TEIXEIRA, 1999).

Pode-se dizer que os calendários escolares, segundo Teixeira (1999), mesmo apresentando períodos quantitativamente homogêneos, expressam um tempo qualitativo. Segundo a mesma autora, há uma variação qualitativa em função dos tipos de atividades e de práticas sociais e, consequentemente, dos ritmos escolares indicados para os períodos. Os dias destinados aos exames e às festas constituem exemplos disso, pois implicam um conjunto específico de rituais e significações diferentes do das semanas normais de aulas, embora tenham igual número de horas/relógio, definidas como semanas ou dias. Os calendários, em suas dimensões qualitativa e quantitativa, refletem as perspectivas, os modos de se pensar e de se fazer educação escolar. Não apenas revelam, mas impõem os ritmos escolares, as cadências das atividades docentes e discentes, prescrevendo suas "durações esperadas socialmente" (MERTON, 1992). Ao estabelecerem a rítmica das atividades educativas, dos tempos e dos espaços escolares, traduzem tanto quanto conformam as opções didático-pedagógicas das escolas e suas formas de realização, uma vez que especificam as atividades a serem desenvolvidas e seus respectivos períodos.

Ao tratarmos das celebrações que imprimiam no cotidiano escolar outros usos do tempo, deve-se atentar para as distinções existentes entre as festividades que ganharam espaço no calendário das escolas primárias e, portanto, diferentes funções, sentidos e 
modos de comemorar. Como desenvolveremos a seguir, o ato de festejar ganhou contornos particulares ao longo do período estudado. Festejava-se para civilizar, divulgar, inaugurar e encerrar o ano letivo. Contrariando a ideia de que o tempo da festa é somente um tempo de descontração e divertimento, as festas escolares constituíam-se tempo de aprender. O exame dos programas, nos quais se propunha a organização dos dias de festa, e das sugestões de atividades a serem realizadas nas comemorações, ambos publicados em revistas especializadas, evidencia o caráter pedagógico das festas, pois estas buscavam ensinar às crianças e aos adultos presentes em tais ocasiões a representatividade de cada data, bem como os valores e as virtudes associados ao novo regime político - a República.

\section{CIVILIZAR, DIVULGAR, INAUGURAR, ENCERRAR 0 ANO LETIVO: OS DIFERENTES SENTIDOS DAS FESTAS ESCOLARES}

O advento da República no Brasil (1889) representa um momento de mudanças sociais, em que se faz necessário compor um novo universo simbólico capaz de conferir legitimidade ao incipiente regime político, e a instituição escolar é eleita pelo novo regime para representar e criar estas transformações. Sabe-se que a criação do aparato educacional no primeiro período republicano - evidenciado nos esforços estatais para a construção de edifícios próprios ao ato de ensinar, na elaboração de uma legislação específica que visava organizar os currículos e os programas escolares, bem como na constituição de um corpo profissional de professores - não acontece de forma instantânea, mas de modo lento e gradativo; os republicanos conseguem concretizar muitas ideias sobre um sistema ideal de ensino, já defendidas pelos dirigentes no Império. Cabe lembrar que esse processo de construção de um modelo escolar no Brasil inserese ainda em um movimento mundial mais amplo, denominado por alguns autores como o momento da "difusão mundial da escola" (SCHRIEWER; NÓVOA, 2000). É em meados do século XIX que acontece a propagação das propostas e das ações para a constituição de sistemas de ensino organizados pelos Estados, com o intuito de generalizar uma educação leiga, obrigatória e gratuita.

A República herda do período imperial as discussões acerca das questões educacionais e diferencia-se deste pela concretização das propostas de uma política nacional de educação, movimento esse que, guardadas as devidas especificidades históricas e condições socioeconômicas, aproxima o Estado brasileiro daquilo que vinha 
sendo realizado em outros países, como o amplo e significativo investimento no setor educacional. No projeto dos idealizadores da República, a educação é o marco que deveria separar um passado obscuro, representado pelo Império, de um futuro luminoso, representativo da República. "Neste âmbito, o papel da educação foi hiperdimensionado: tratava-se de dar forma ao país amorfo, de transformar os habitantes em povo, de vitalizar o organismo nacional, de constituir a nação" (CARVALHO, 1989, p. 9)4, demonstrando, como afirma Viñao Frago (1995), a crença messiânica dos reformadores da educação de que seria possível uma total ruptura entre o passado e o presente por meio de reformas educacionais, no sentido de "regenerar as populações brasileiras, núcleo da nacionalidade, tornando-as saudáveis, disciplinadas e produtivas, eis o que se esperava da educação, erigida nesse imaginário em causa cívica de redenção nacional" (CARVALHO, 1989, p. 10).

O significativo apelo aos valores cívicos e o culto aos símbolos nacionais são representativos da tentativa de estabelecer a unidade e a integração social (SOUZA, 2000). A democracia, a federação e a educação emergem como elementos imprescindíveis, tal como se afirmava, para empreender a "salvação" e o progresso do país. $\mathrm{O}$ discurso dominante era o de que a educação solucionaria todos os problemas sociais, econômicos, políticos, enfim, regeneraria o homem e a sociedade. A institucionalização das escolas era concebida, nesse contexto de consolidação de uma nova ordem política, como um marco "a sinalizar a ruptura que se pretendia instaurar entre um passado de obscurantismo e um futuro luminoso" (CARVALHO, 1989, p. 55).

As escolas são reconhecidas, principalmente nos primeiros anos republicanos, não só como responsáveis pelo aprendizado dos conteúdos escolares, mas como encarregadas de uma função mais abrangente, que era ensinar formas adequadas de se comportar e agir na sociedade. Nesse sentido, a adoção de determinados comportamentos esteve fortemente influenciada pelos valores de certos grupos sociais, geralmente das camadas sociais mais abastadas (DUSSEL, 2000). Assim, a escola deveria privilegiar atitudes (disciplina, ordem, obediência) muitas vezes distantes dos modos de vida dos trabalhadores, mas que garantiriam a formação de pessoas dóceis e disciplinadas, favorecendo as exigências da modernidade (CARVALHO, 1989). Sob a ótica do nacionalismo vigente, a escola era a instituição fundamental, engendrada pela "nação" para formar o cidadão. Sendo assim, a escola paulista deveria "cuidar de transformar o caboclo, o imigrante e o operário em cidadãos brasileiros" (BITTENCOURT, 1988, p. 45). 
Desse modo, as instituições escolares integravam um projeto modernizador e difundiam valores, a exemplo do calendário escolar, que, ao eleger e selecionar datas a serem festejadas, bem como homens a serem considerados heróis, indica o que deve ser lembrado e, consequentemente, produz esquecimentos. Heróis e mitos são criados e cultivados; fazia-se necessário desencadear emoção, encontrar símbolos dos fatos que se desejava recordar e provocar sentimentos para que as crianças aderissem a estes com paixão. Era preciso fazer com que o povo amasse a pátria, seus heróis, comemorasse a era republicana: hinos, hasteamento da bandeira, pavilhão escolar, músicas cujas letras faziam menção à pátria foram atividades decisivas na constituição da memória coletiva oficial.

As comemorações cívicas promovidas pelas escolas primárias marcaram um momento importante da inserção do tempo escolar no tempo social, uma vez que, antes da constituição das escolas graduadas (grupos escolares), o mais comum era o fechamento das escolas públicas para que as crianças participassem dos festejos sociais, fossem eles cívicos ou religiosos, visto que a instituição escolar pública ainda não havia conquistado a sua legitimidade social. Desse modo, as festas escolares, ao contrário das festas do calendário social, não contrapunham o tempo livre ao tempo do trabalho, uma vez que constituíam tempo de atividade educativa, um tempo para aprender. Conforme salienta Oliveira (1989, p. 185),

\footnotetext{
os republicanos instituíram suas festas procurando estabelecer uma continuidade com eventos históricos passados; valorizaram a lembrança de feitos e heróis até então perdedores. A República os resgatava em sua dignidade e valor. A proposta da tradição republicana não destacava a singularidade do país e sim seu pertencimento a uma fraternidade com países e/ou momentos visualizados como representantes do lema: liberdade, igualdade, fraternidade.
}

Tais afirmações ficam evidentes ao retomarmos parte de textos publicados por Carlos A. Gomes Cardim (1916), As comemorações cívicas e As Festas Escolares, e Assis Cintra, intitulado Alma Brasileira (1916?), publicados em São Paulo. Esses livros merecem destaque por serem os primeiros trabalhos localizados que trataram do tema "festas nas escolas" no período em questão. As festas escolares, segundo esses autores, são concebidas como a principal forma de "alimentar" sistematicamente na infância o "lume" do patriotismo latente (CARDIM, 1916), além de representarem os avanços alcançados por um país. De acordo com Cintra (1916?), “os países civilizados despertam na alma do povo, através das festas e comemorações, a nobreza de três grandes sentimentos: o amor da Pátria, a fraternidade humana e 
o culto da liberdade", além disso, "é o conjunto comemorativo que ensina ao povo a santa trindade das civilizações modernas: Pátria, Paz e Liberdade" (CINTRA, 1916?, p. 6). Nas palavras de Cardim (1916), o sentimento de pátria e o culto de tudo que diz respeito a essa bela manifestação da alma devem nascer no lar, desenvolver-se na escola e disseminar-se para a sociedade, mas, para que esse fato se manifeste nessa ordem, é preciso supor um trabalho prévio na escola. Segundo defendido por Cardim (1916, p. 03),

é necessário que, ai, se tenha formado a alma da criança na escola do civismo, é necessário que se tenha robustecido o seu caráter na escola do dever, para que depois, se consiga, no lar, progenitores capazes de encarregarem-se da nobre missão de desenrolar, aos olhos dos filhos, o painel sublime da pátria, capazes de segredar-lhes ao coração as belezas históricas do passado, capazes de desenvolver, os episódios épicos em torno dos grandes vultos do país.

O civismo é concebido pelos educadores da época como a vertente educacional privilegiada para a formação do cidadão republicano e para a concretização e a disseminação dos ideais políticos no sistema educacional. Por esse motivo, o civismo permeou várias atividades escolares, como as aulas de história, os rituais de hasteamento da bandeira nacional, os hinos pátrios aprendidos nas aulas de música e apresentados em ocasiões solenes e as festas comemorativas de eventos ou de homenagens aos heróis nacionais, como as datas: 21 de Abril, comemoração dos precursores da Independência; 7 de Setembro, data do "Grito do Ipiranga"; 15 de Novembro, Proclamação da República; e 19 de Novembro, festa da Bandeira Nacional. Assim, as escolas públicas, especialmente os grupos escolares, se fundaram como o lugar onde se ensinavam e se aprendiam os valores cívicos, além de serem instituições guardiãs desses valores, cuja ação moral e pedagógica deveria se estender para toda a sociedade.

As festas escolares, que não se resumiam às comemorações das datas cívicas oficiais, deveriam contribuir para o novo regime, demonstrando o progresso do Estado de São Paulo e do país, apresentando um novo modelo de cidadão republicano a ser incorporado por todos e contribuindo para a constituição de um imaginário político, histórico e social consoante às novas propostas dos dirigentes. De acordo com Nunes (2003), o civismo não estava presente somente nas comemorações escolares, mas permeou todo o âmbito das escolas primárias por meio das várias imagens cívicas.

Com relação aos significados das datas escolhidas a serem comemoradas no âmbito escolar, Cintra (1916?) as distingue em três eixos principais: o da fraternidade universal, o da pátria e o da liberdade. 
No primeiro grupo estão as datas: $1^{\circ}$ de Janeiro, dia de "Ano Bom"; 12 de Outubro, descoberta da América; 2 de Novembro, dia de Finados; e 25 de Dezembro, nascimento de Cristo. No segundo grupo estariam as datas: 3 de Maio, dedicado às comemorações patrióticas; 21 de Abril, comemoração dos precursores da Independência; 7 de Setembro, data do "Grito do Ipiranga"; 15 de Novembro, Proclamação da República; e 19 de Novembro, festa da Bandeira Nacional. Já o terceiro grupo inclui as datas: 14 de Julho, dia da "liberdade dos homens"; 13 de Maio, abolição da escravatura; e 24 de Fevereiro, comemoração da Constituição Brasileira (CINTRA, 1916?).

Essas datas foram regulamentas pelo Decreto n. 144B, de 30 de dezembro de 1892, que dispõe sobre os dias de festa nacional no Brasil. A instituição das festas, de acordo com o referido decreto de 1892, representa o estabelecimento da fraternidade universal inerente a qualquer regime republicano, capaz de comemorar a continuidade e a solidariedade de todas as gerações humanas. Com relação aos feriados previstos, não se percebem alterações significativas em relação ao que foi estabelecido desde o início da década de 1890. Outro aspecto importante a ser notado é que as datas cívicas prevaleciam em relação às religiosas, entretanto, no caso das festas cívicas, estas eram promovidas pelas escolas, mas, no caso dos feriados religiosos, como a Semana Santa e o Dia dos Mortos, as escolas fechavam as suas portas. As festas escolares deveriam ser comemoradas de acordo com as regras vigentes: os dias eram regulamentados pela legislação; os hinos, as poesias e as peças teatrais, sugeridos em livros e nos periódicos destinados aos professores; os programas eram exemplificados em circulares elaboradas pelos inspetores e os diretores de ensino e destinadas aos professores. Tudo era prescrito e regulamentado, denotando-se, desse modo, a preocupação com a potencialidade educativa das comemorações.

A prática das festas cívicas tinha como objetivo representar e celebrar a identidade e a soberania de um país independente, fomentar o "sentimento republicano" do povo, consolidar um modelo de escola e configurar uma cultura escolar. Os exemplos do mestre, dos alunos e dos grandes nomes da história do Brasil também serviam ao ensino do civismo e da moralidade. A temática do herói nacional - representado, por exemplo, por Tiradentes - tinha como função inculcar aos pequenos leitores certa forma de pensar e viver a nacionalidade. O "herói" da Inconfidência Mineira, considerada um marco para outros movimentos, como a Abolição da Escravatura e a Proclamação da República, foi recuperado pelos republicanos como 
personagem importante para a construção de uma identidade nacional coletiva. A Inconfidência Mineira é escolhida como momento histórico precursor da construção do Estado independente, e os inconfidentes, como precursores do republicanismo (LIMA E FONSECA, 2002).

Os programas publicados nas revistas pedagógicas, os quais são dirigidos aos professores de modo a orientar as comemorações nas diferentes escolas, propunham entre as atividades relativas às festas cívicas juramento à bandeira, poesias e hinos a serem recitados e cantados pelos alunos, apresentação de pequenas peças teatrais, de ginástica e de exercícios físicos, discursos de professores ou de autoridades educacionais, ou seja, homenagens aos heróis nacionais e às autoridades, e, algumas vezes, desfiles e lanches servidos para os alunos e seus familiares. Os programas variavam de acordo com o tipo da instituição escolar (grupo escolar, escola isolada, escola reunida, escola-modelo), com a data a ser comemorada e com o contexto no qual aconteceriam as atividades. Tal como relatado, em 1907, na Revista de Ensino a propósito da realização das festas nas escolas públicas,

a primeira parte do programa era entrecortada de poesias e páginas patrióticas, como - Minha Terra, A S. Paulo, Pátria Livre, Ao Brasil, Sete de Setembro, O Suplício de Tiradentes, A República, Um Episódio da Guerra do Paraguai, etc e amenizada por cânticos harmoniosos ou salmos em louvor às nossas glórias e datas. [...]

Em cada sala, os alunos, ao som de Hynno à Bandeira, desfilavam pela frente ou ao redor do pavilhão, jogando-lhe flores. Faziam-lhe, ao mesmo tempo, continência e saudação. (FELICIANO, 1907, p. 89-90).

Além das datas cívicas, ainda se constituíam momentos a serem celebrados inaugurações e aniversários das instituições escolares e o encerramento do ano letivo, quando se realizavam os exames e a entrega de prêmios aos melhores alunos. Assim, as festividades ocorriam para celebrar os aspectos que ainda eram novidades na cultura das escolas públicas primárias, dando visibilidade ao modelo de educação escolar inspirado em países considerados civilizados, como França, Inglaterra, Suíça, Alemanha, entre outros. A criação de uma escola pública, de modo especial, de um grupo escolar, representou a garantia não só de educação para as crianças, mas de um ensino mais metódico do que aquele que acontecia nas escolas de um só professor ou isoladas ${ }^{5}$.

Cabe destacar que tais festas eram recorrentes no primeiro decênio republicano, e seus objetivos se constituíam não só da demonstração dos avanços alcançados em termos da difusão do ensino possibilitada pela construção de novos prédios como também da consolidação da importância da escola primária. Segundo João 
Beckmaum (1908), as festas de inauguração visavam a demonstrar o desenvolvimento e o progresso das escolas públicas republicanas para professores, alunos, pais e sociedade, para que não houvesse nenhuma dúvida acerca da qualidade das mesmas. Carvalho (1989), retomando os ideais dos educadores publicados nas revistas especializadas da época, sintetiza:

Para fazer ver, a escola devia se dar a ver. Daí os edifícios necessariamente
majestosos, amplos e iluminados, em que tudo se dispunha em exposição
permanente. Mobiliário, material didático, trabalhos executados, atividades
discentes e docentes - tudo devia ser dado a ver, de modo que a conformação
da escola aos preceitos da pedagogia moderna evidenciasse o progresso que a
República instaurava. (CARVALHO, 1989, p. 25)

Todos os esforços feitos no sentido da organização de um sistema de ensino público, desde a redação das leis até a construção dos edifícios, deveriam ser conhecidos pelo maior número possível de pessoas, e, para a realização de tal intuito, os festejos escolares assumiam papel principal. A celebração dos aniversários de fundação das instituições de ensino representava um avanço, o reconhecimento do tão almejado progresso do país, sendo que a população costumava aceitar com grande entusiasmo tais acontecimentos, como atesta a notícia de inauguração de um grupo escolar em Bragança:

No dia nove de agosto passado inaugurou-se na cidade de Bragança o grupo escolar criado pelos constantes esforços do distinto inspetor escolar Sr. Raphael de Lima.

A cerimônia da inauguração foi feita com grande regozijo da população, que via naquele ato a garantia de um ensino mais metódico do que se dá nas escolas isoladas.

Parabéns ao povo de Bragança e ao digno inspetor pelo novo melhoramento. (A Eschola Publica, 15 de setembro de 1897, p. 277)

Certamente, a criação e a difusão dos grupos escolares no Estado de São Paulo significaram mudanças expressivas nas representações sociais acerca da educação escolar e nas possibilidades do almejado progresso brasileiro.

Outro momento importante para demonstrar o avanço alcançado pelas crianças que frequentavam as escolas públicas eram as festas de encerramento do ano letivo. Os programas publicados e distribuídos, dirigidos exclusivamente às orientações das festas de encerramento pelo "Boletim" da revista $A$ Eschola Publica, particularmente na edição de dezembro de 1896, diferenciavamse dos demais pela inclusão de certos rituais que não compunham o programa das outras solenidades, como: os exames finais sobre as disciplinas estudadas durante o ano letivo, nos quais os alunos 
deveriam demonstrar os resultados obtidos em todo o ano de estudo e dedicação; a distribuição dos boletins de promoção; e os prêmios aos melhores alunos. Os exames realizados em algumas escolas tornaram-se rituais de grande projeção pública, representando uma das normas de excelência da escola primária paulista. "Para as bancas examinadoras eram convidados políticos e autoridades locais, portanto, tratava-se de uma validação social do ato de classificação de inegáveis consequências políticas e sociais" (SOUZA, 1998, p. 244). A sessão era acompanhada pelos pais e pela população ${ }^{6}$.

Apesar de constituírem uma ruptura na rotina dos professores e dos alunos, esta, marcada por "aulas-recreio-aulas", as festas também visavam ensinar, fosse a partir de seus rituais, nos quais se celebrava por meio das apresentações e dos comportamentos tidos como ideais, os quais sugeriam uma determinada forma de ser e estar na sociedade; fosse por meio de seus discursos, pronunciados muito mais para a população de adultos, pais e professores presentes a essas ocasiões do que para as crianças. As festas intentavam ensinar os conteúdos das datas cívicas e, dessa forma, buscavam contribuir para a construção de uma memória histórica coletiva; para o amor à pátria, representado pelas festas que valorizavam nossa natureza; demonstravam a importância da educação, celebrada nas festas de inauguração, de formatura e de encerramento do ano letivo; representavam a educação estética, por meio de todo o ritual que as envolvia; nos seus discursos, apresentava-se um quadro geral da educação e das questões na ordem do dia em um determinado contexto histórico.

Ao serem observadas as mudanças nas comemorações festivas na escola no período em que a escola primária passava por reformulações importantes para a sua história, destaca-se que essas transformações impuseram redefinições nos modos de entender a função e o papel dos professores, solicitando a estes novas práticas e ações consonantes aos ideais que o regime político instituído atribuiu à educação.

\section{O GLAMOUR DAS FESTAS E A CONTESTAÇÃO DA SUA REAL NECESSIDADE}

Se, em um primeiro momento, as festas eram valorizadas como artifício para a confirmação dos avanços do governo no campo educacional e para a propaganda das escolas públicas, após alguns anos de implantação do sistema de ensino, sua potencialidade passa a ser contestada, e as festividades são apresentadas até como uma das causas perturbadoras do ensino, sem nenhuma utilidade para o fim da educação. Uma das primeiras críticas às festas escolares foi publicada na Revista de Ensino em 1908, em artigo assinado por 
João Beckmaun (1908). Naquela oportunidade, o autor argumenta que as festas escolares já haviam cumprido a sua função, que era a de tornar bem explícito o desenvolvimento das primeiras escolas republicanas, e não se faziam mais necessárias, sendo até mesmo prejudiciais, devido aos grandes exageros ocorridos nas ocasiões: "temos assistido a verdadeiras exibições teatrais, incompatíveis com a natureza essencialmente prática e educativa dos estabelecimentos de ensino, o que não deixa de revelar perda de tempo, que podia ser empregado em coisas mais úteis" (BECKMAUM, 1908, p. 36).

As festas deviam ser, para o autor, uma repetição bemorganizada e bem-selecionada de aulas dadas durante o ano letivo, como já era realizado em algumas escolas. Dever-se-iam, assim, trocar os hábitos dos festejos pelos que estavam se iniciando nas escolas, como os de comemorar as datas nacionais, como a Festa da Bandeira, os quais consistiam em uma "importância decisiva na educação, e cuja comemoração podia ser realizada como festas íntimas, como as aulas cívicas, sem pompas, nem aparatos" (BECKMAUM, 1908, p. 36). Além do seu caráter teatral, o potencial educativo das festas também é contestado por Guilherme Kuhlmann (1919), que afirma em artigo que as festas nacionais traziam um "minguado ensino cívico [...], poucos resultados". Ainda segundo Kuhlmann (1919), o ensino cívico deveria "ser [a] principal preocupação, em todas as aulas", já que a disciplina consta no programa do curso primário e tem lugar determinado no horário (KULMANN, 1919, p. 15).

Críticas como essas também são expressas em relatórios de inspetores publicados nos Anuários de Ensino do Estado de São Paulo, nos quais foram localizados dois artigos que teciam críticas ao hábito de festejar. Desses textos, vale destacar o relatório do inspetor de ensino Miguel Carneiro Júnior (1908-1909), no qual o educador assinala tudo que lhe parece "mau" no sistema escolar e, entre as causas perturbadoras do ensino, aponta as festas escolares.

14. Festas Escolares

Uma outra causa perturbadora do ensino, são as festas de caráter mais ou menos teatral, com que muitos grupos escolares e algumas escolas isoladas encerram os trabalhos do ano letivo.

Essas festas, de valor educativo muitíssimo contestável, perturbam extraordinariamente o ensino, por causa dos ensaios que exigem.

As crianças, no entusiasmo das festas em preparo, esquecem os preceitos disciplinares, abandonam os estudos e adquirem o hábito pernicioso da vadiagem.

A escola deve ser alegre, deve ser festiva, para que a criança se sinta bem nela, mas, por certo, não será com a interpretação de comédias e revistas que tal intuito se conseguirá. (CARNEIRO JÚNIOR, 1908-1909, p. 72) 
Pelo que se percebe, parece que parte das críticas às festas justificou-se pelo fato de essas ocuparem muito tempo com preparações e não surtirem o efeito desejado. Além disso, por serem comemoradas no dia do feriado, não contentavam os professores, que perdiam o dia de descanso. Talvez fosse esse o motivo de tais festejos ocorrerem em algumas escolas na véspera, como reclama o inspetor Aristides de Macedo (1910-1911, p. 100): “as comemorações cívicas deveriam ser realizadas na data correta, e não na véspera como costumava acontecer". Para o inspetor, "essas constituíam uma ótima oportunidade para a educação moral e cívica e para a formação do patriotismo na criança" (MACEDO, 1910-1911, p.107).

Por outro lado, noticia-se na Revista Escolar (n. 12, ano 1, 01/12/1925, p. 101) sobre a festa de 15 de Novembro: "esta grande festa nacional foi brilhantemente comemorada em todos os nossos estabelecimentos de ensino [...]. O dia seguinte, segunda-feira, foi feriado nas escolas para descanso de alunos e professores". Pelo fato de essa notícia datar da década de 1920, pode ser que, alguns anos depois de terem sido instituídas as festas, as reivindicações dos professores tenham sido acolhidas, e o descanso, garantido depois das celebrações.

Se de um lado, no fim da década de 1900, havia sugestões para acabar com os festejos do fim de ano nos grupos escolares por não serem mais necessários, de outro se noticiava, em relação às escolas isoladas da capital, que o governo oferecesse aos professores e aos alunos a garden-party, a qual, segundo João Lourenço Rodrigues (1907-1908, p. 65), consistia em um "prenúncio de uma nova era para as escolas isoladas". Na verdade, tal fato evidencia que, na impossibilidade de exterminar as escolas isoladas, procurava-se fazer propaganda destas, já que a reputação dos grupos estava consolidada e estes não eram em número suficientes para suprir a demanda de alunos. Noticiavase que eram reunidas numa festa coletiva as escolas isoladas, a fim de inculcar ao espírito dos professores que elas eram isoladas só quanto ao tipo de organização e, dessa forma, deveriam formar "pelo critério e esforço de quem as rege um aparelho harmônico e militante nas lides do ensino" (RODRIGUES, 1907-1908, p. 64).

\section{CONSIDERAC̣̃̃ES FINAIS}

Mediante o que foi discutido até aqui, é conveniente tratar as festas escolares também na sua pluralidade. A cultura escolar e seus elementos, como as festas enquanto um dos importantes marcadores temporais constituídos do período aqui discutido, transformaram- 
se no decorrer do tempo, segundo as sociedades, as políticas e até mesmo as finalidades religiosas (JULIA, 2001), sendo que sua repercussão não fica restrita ao âmbito escolar, formando somente os indivíduos que frequentam as escolas, mas também penetra, molda e modifica a cultura da sociedade global (CHERVEL, 1990). Isso pode ser observado no caso das festas escolares, cujo propósito inicial era deixar bem patente para a sociedade o desenvolvimento admirável e real das crianças educadas nas primeiras escolas públicas paulistas.

Considerando-se as notícias publicadas nos periódicos da época pelos docentes que atuavam na área educacional, é possível afirmar que, num primeiro momento, um grande número de artigos acerca das festas de aniversário, de inauguração e encerramento do ano letivo almejou, além de dar visibilidade aos avanços alcançados pelos dirigentes republicanos no âmbito educacional, demonstrar o desenvolvimento das crianças educadas nas primeiras escolas republicanas.

As festas que buscavam mostrar o avanço e o progresso das instituições escolares no começo do século passaram a dividir as atenções com outro tipo de festa: as festas cívicas, que confirmavam a potencialidade pedagógica dessa atividade. O civismo, a moral, os bons costumes, o bom cidadão, os grandes heróis e nomes da nossa história foram temas de diversos festejos. Assim, se as festas foram importantes em um primeiro momento para a consolidação dos ideais republicanos e para dar visibilidade à escola pública, em um momento posterior, esse objetivo foi contestado; elas continuaram acontecendo, mas com outros sentidos e propósitos que não os mobilizados inicialmente.

Pode-se atribuir essa alteração no papel das festas à própria assimilação dessas na cultura escolar. Ao fazerem parte de um modo cada vez mais recorrente do cotidiano escolar, constituindo-se em um dos aspectos da cultura específica da escola, as festas, ao serem alcançados os objetivos explicitados, não eram mais necessárias como uma novidade educacional. Quando os grupos escolares foram criados, muitas eram as mudanças a serem incorporadas por professores, alunos e também pelos pais. Nesse sentido, as festas consistiram em um dos vários aspectos introduzidos e que, gradativamente, entranharam-se nas representações sociais que compõem a cultura escolar.

\section{REFERÊNCIAS}

BECKMAUM, João. Discurso proferido no ato de colação de grau às professorandas normalistas. Revista de Ensino, dezembro de 1908, ano VII, n. 4, p. 26-36.

BITTENCOURT, Circe. As "Tradições Nacionais" e o Ritual das Festas Cívicas. In: PINSKY, J. et al. O ensino de bistória e a criação do fato. São Paulo: Contexto, 1988. p. $43-73$. 
CARDIM, Carlos Augusto Gomes. As comemorações civicas e as festas escolares. São Paulo: Augusto Siqueira \& C., 1916. 122 p.

CARVALHO, Marta Maria Chagas de. A escola e a República. São Paulo: Brasiliense: Col. Tudo é História, 1989.

CATANI, Denice Barbara. Educadores à meia-luæ: um estudo sobre a Revista de Ensino da Associação Beneficente do Professorado Público de São Paulo. Bragança Paulista, SP: EDUSF, 2003.

CHARTIER, Roger. A História Cultural: entre práticas e representações. Lisboa: Difel, 1990. CHERVEL, André. História das disciplinas escolares: reflexões sobre um campo de pesquisa. Teoria \& Educação, Porto Alegre, n. 2, p. 177- 229, 1990.

DURKHEIM, Émile. As formas elementares da vida religiosa: o sistema totêmico na Austrália. São Paulo: Paulinas, 1989.

DUSSEL, Inés. Historias de guardapolvos y uniformes: sobre cuerpos, normas e identidades em la escuela. In: GVIRTZ, Silvina. Textos para repensar el día a día escolar. Sobre cuerpos, vestuários, espacios, lenguajes, rytos y modos de convivencia en nuestra escuela. Buenos Aires: Ediciones Santillana, 2000, p. 105-132.

ESCOLANO, Agostín. Os profesores na história. Porto: Sociedade Portuguesa de Ciências da Educação, 1999, p. 15-28.

FARIA FILHO, Luciano Mendes et al. A cultura escolar como categoria de análise e como campo de investigação na história da educação brasileira. Educação e Pesquisa, São Paulo, v. 30, n. 1, p. 139-160, 2004.

FELICIANO, José. As comemorações cívicas e a educação moderna (simples observações aos meus alunos). Revista de Ensino, novembro de 1907, p. 85-90.

FRAGO, Antônio Viñao. Historia de la educación e historia cultural. Revista Brasileira de Educação. ANPED, n. 0, p. 63-82, set./dez.1995.

JULIA, Dominique. A cultura escolar como objeto histórico. Revista Brasileira de História da Educacão, Maringá, n. 1, p. 9-43, jan./jun. 2001.

JUNIOR, Miguel Carneiro. Relatório do Inspetor Miguel Carneiro Junior. Anuários de Ensino do Estado de São Paulo. São Paulo, 1908-1909, p. p. 57-72.

KUHLMANN, Guilherme. As festas escolares. Revista de Ensino, ano 17, jun-dez/1918 publicado em out/1919, p. 15,

LE GOFF, Jacques. História e memória. Campinas: Editora da UNICAMP, 1994.

LIMA E FONSECA, Thaís Nívia de. O herói nacional para crianças: produção e circulação de imagens de Tiradentes na escola primária brasileira. In: REUNIÃO ANUAL DA ASSOCIAÇÃO NACIONAL DE PÓS-GRADUAÇÃO E PESQUISA EM EDUCAÇÃO: educação: manifestos, lutas e utopias. 25., 2002, Caxambu. Anais... Caxambu: ANPED, 2002. v. 1. p. 1-17.

MACEDO, Aristides de. Relatório do Inspetor Escolar Aristides de Macedo. Anuários de Ensino do Estado de São Paulo. São Paulo, 1910-1911, p. 100-107.

MERTON, Robert. Las duraciones esperadas socialmente: un estudio de caso sobre la formación de conceptos en sociología. In: TORRE, Ramón Ramos (Org.) Tiempo y sociedad. Madrid: Siglo Veintiuno de España Editores, 1992.

NAGLE, Jorge. A Educação na Primeira República. In: FAUSTO, Boris (org.), O Brasil Republicano. Rio de Janeiro: Difel, 1978, p. 261-291. 
NUNES, Clarice. (Des)encantos da modernidade pedagógica. In: LOPES, Eliana Marta Teixeira; FARIA FILHO, Luciano Mendes; VEIGA, Cynthia Greive (orgs.). 500 anos de educaşão no Brasil. Belo Horizonte: Autêntica, 2000, p. 371-398.

OLIVEIRA, Lúcia Lippi. As festas que a República manda guardar. Estudos Históricos. Rio de Janeiro, vol. 2, n. 4, 1989, p. 172-189.

RODRIGUES, João Lourenço. Relatório apresentado ao Exmo. Snr. Secretario dos Negócios do Interior pelo Professor João Lourenço Rodrigues. Anuários de Ensino do Estado de São Paulo. São Paulo, 1907-1908, p. 63-66.

SOUZA, Rosa Fátima de. Templos de Civilização: a Implantação dos Grupos Escolares no Estado de São Paulo (1890-1910). São Paulo: Fundação Editora da UNESP, 1998.

Rituais escolares: liturgia cívica e glorificação da memória (aproximações históricas). In: PORTO, SANCHEZ TEIXEIRA, FERREIRA SANTOS \& BANDEIRA (orgs.). Tessituras do Imaginário: cultura \& educação. Cuiabá: Edunic/CICE/FEUSP, 2000. p. 173-184. SCHRIEWER, J.; NÓVOA, A. A difusão mundial da escola. Lisboa: Educa, 2000.

TEIXEIRA, Inês Assunção de Castro. Cadências escolares, ritmos docentes. Educação e Pesquisa, São Paulo, v. 25, n. 2, p. 87-108, jul./dez. 1999.

VIDAL, Diana Gonçalves. Culturas Escolares: um estudo sobre práticas de leitura e escrita na escola pública primária (Brasil e França, final do século XIX). Campinas, SP: Autores Associados, 2005.

\section{NOTAS}

${ }^{1} \mathrm{O}$ presente artigo foi elaborado a partir das pesquisas realizadas pelas autoras em nível de mestrado e doutorado, a saber: GALLEGO, Rita de Cassia. Uso(s) do tempo: a organização das atividades de alunos e professores nas escolas primárias paulistas (1890-1929). 2003. 189 $\mathrm{f}+$ anexos. Dissertação (Mestrado em Educação) - Faculdade de Educação, Universidade de São Paulo, São Paulo. 2003; Tempo, temporalidades e ritmos nas escolas primárias públicas em São Paulo: heranças e negociações (1846-1890). 2008. 328 f + anexos. Tese (Doutorado em Educação) - Faculdade de Educação, Universidade de São Paulo, São Paulo. 2008; CANDIDO, Renata Marcílio. A máquina de festejar: os usos e funções das festas escolares no Brasil e Portugal (1870-1960). 2012. 309 f + anexos. Tese (Doutorado em Educação) - Faculdade de Educação, Universidade de São Paulo, São Paulo. 2012.

${ }^{2} \mathrm{O}$ cume das mudanças das práticas educativas consiste, no caso brasileiro, na criação dos grupos escolares, a partir da década de 1890, em diversos Estados. Os grupos escolares influenciam significativamente a construção do modelo de escola primária, cujas marcas são notadas até hoje, e a consolidação das pretensões de modernidade difundidas no âmbito social desde meados do século XIX. Durante os anos de 1870 e no início do século XX, esse tipo de escola começa a ser pensada e proposta. Trata-se da chamada escola de massas, um modelo de ensino instituído a partir do esforço e da tentativa do Estado para ampliar as vagas nos bancos escolares para toda a população, de maneira leiga, gratuita e obrigatória à guisa do que estava em curso em países como França, Alemanha, Espanha, Portugal, entre outros. Os grupos escolares, criados em 1893, no caso de São Paulo, marcaram a história das instituições escolares por instaurarem mudanças significativas na organização administrativa e pedagógica da escola primária, com o sistema graduado, presente em diversos países ocidentais desde o século XIX. A esse respeito, ver o trabalho de Rosa Fátima de Souza (1998). 
${ }^{3}$ Emprega-se o termo "escolas", no plural, considerando-se a diversidade dos estabelecimentos de ensino primário que havia no período dedicado para estudo. Coexistiam as escolas-modelo (criadas pela reforma de 1890), os grupos escolares ou escolas graduadas (criados em 1893), as escolas reunidas (que não tinham número de alunos suficientes para se formar um grupo escolar) e as escolas isoladas (com um único professor e alunos de diferentes idades e níveis de ensino no mesmo espaço). Entre essas, é notável o caráter modelar assumido pelas escolasmodelo e pelos grupos escolares, especialmente no que concerne à organização temporal (calendário e divisão das atividades no dia de aula) e, consequentemente, às festividades e às comemorações, que passaram a integrar o cotidiano das escolas. Além dessa distinção, hão que se levar em conta as diferenças entre os estabelecimentos localizados na zona urbana e na zona rural, diferenças estas que, devido aos propósitos deste artigo, não serão exploradas.

${ }^{4}$ Cabe referenciar outros estudos que elegeram como objeto de investigação aspectos da educação brasileira na chamada primeira república (1890-1930): Nagle (1978); Carvalho, (1989); Catani (2003); Gallego (2003).

${ }^{5}$ Embora se almeje a substituição das escolas isoladas pelos grupos, estas permanecem funcionando durante todo o período estudado. Mesmo com o gradativo crescimento do número de grupos escolares, eram insuficientes para o atendimento da demanda de alunos.

${ }^{6}$ Deve-se destacar que os exames ganharam diferentes configurações no decorrer do período estudado: a princípio, só ocorriam no fim do ano (novembro, dezembro), fazendo-se presente todo um ritual, de modo que todos, matriculados ou não nas escolas públicas, podiam fazêlos para dar continuidade aos estudos. Com a organização dos grupos, somaram-se aos exames finais os trimestrais, bimestrais ou, ainda, mensais, pois se tratava de garantir a homogeneidade entre os alunos da mesma turma, condição para a dinâmica da escola seriada em formação. Embora os exames ainda fizessem parte das festas de encerramento, com a gradativa organização dos grupos, esses foram incorporados à cultura escolar e, assim, não constituíam mais situações de divulgação da escola para a sociedade (GALLEGO, 2003).

Recebido: 06/05/2013

Aprovado: 15/04/2015

Contato:

Universidade de São Paulo

Faculdade de Educação

Av. da Universidade, 308 - Butantã

São Paulo|SP|Brasil

CEP 05.508-040 